\title{
Decomposition and release of elements from zooplankton debris
}

\author{
Byeong-Gweon Lee, Nicholas S. Fisher* \\ Marine Sciences Research Center, State University of New York, Stony Brook, New York 11794-5000, USA
}

\begin{abstract}
In experiments examining the retention of trace elements in decomposing zooplankton debris, the rates of $\mathrm{C}$ degradation and metal release from radiolabeled copepod fecal pellets and carcasses were measured for up to 1 mo using radiotracers. Fecal pellets incubated at 18 and $2{ }^{\circ} \mathrm{C}$ retained 35 to $40 \%$ and $80 \%$ of their ${ }^{14} \mathrm{C}$, respectively, after $30 \mathrm{~d}$. Carcasses retained only 13 to $18 \%$ and 28 to $38 \%$ of their ${ }^{14} \mathrm{C}$ after $18 \mathrm{~d}$ at 18 and $2{ }^{\circ} \mathrm{C}$, respectively. Leaching of ${ }^{14} \mathrm{C}$ from fecal pellets and carcasses as $\mathrm{DO}^{14} \mathrm{C}$ accounted for about half of the ${ }^{14} \mathrm{C}$ loss, even in the absence of microbial activity. Proportionately more of the ${ }^{14} \mathrm{C}$ from carcasses was microbially oxidized to ${ }^{14} \mathrm{CO}_{2}$ than ${ }^{14} \mathrm{C}$ from fecal pellets. Release of the particle-reactive transuranic element ${ }^{241} \mathrm{Am}$ from fecal pellets was unaffected by microbial activity while release of ${ }^{75} \mathrm{Se}$ and ${ }^{65} \mathrm{Zn}$ from both fecal pellets and carcasses increased with microbial activity and closely followed ${ }^{14} \mathrm{C}$ loss. Release rates of all elements decreased exponentially over time, with the most pronounced decreases occurring within the first $6 \mathrm{~d}$. Retention half-times $\left(t_{\mathrm{r} 1 / 2} s\right)$ of ${ }^{241} \mathrm{Am}$ were $\geq 48 \mathrm{~d}$ in fecal pellets. By contrast, the $t_{\mathrm{r} 1 / 2}$ 's for ${ }^{65} \mathrm{Zn}$ ranged from 2.1 to $13.5 \mathrm{~d}$ in fecal pellets and both ${ }^{65} \mathrm{Zn}$ and ${ }^{75} \mathrm{Se}$ had $t_{\mathrm{r} 1 / 2}$ 's of only about $1 \mathrm{~d}$ in carcasses. The results help explain oceanographic observations that $\mathrm{C}$. Se and $\mathrm{Zn}$ are recycled in surface waters while scavenged elements like Am are enriched in fecal pellets and have short residence times in surface waters.
\end{abstract}

\section{INTRODUCTION}

Numerous studies have shown that large biogenic particles are important vectors for the vertical transport of organic compounds, radionuclides and metals from the surface ocean to the deep ocean (McCave 1975, Knauer et al. 1979, Wakeham et al. 1984, Fowler \& Knauer 1986, Fisher et al. 1988). These particles include phytoplankton aggregates, zooplankton fecal pellets, eggs, molts, animal carcasses, larvacean houses, and marine snow. Among these particles, fecal pellets in particular have received considerable scrutiny due to their ubiquity, abundance and rapid sinking rates. The geochemical cycling of many elements is strongly influenced by sinking particles during their descent in the water column, either through oxidation or dissolution of the particles or by scavenging of particle-reactive elements from ambient water.

\footnotetext{
- Addressee for correspondence
}

The flux of particles measured by sediment traps indicates that particles are rapidly regenerated beneath the euphotic zone (Knauer et al. 1979. Hargrave 1985, Martin et al. 1987). Although information on the degradation of these organic particles is essential to understanding the geochemical cycling of nutrients and metals in the ocean, the fate of settling biogenic particles is not well understood and explanations of processes responsible for degradation are controversial (Cho \& Azam 1988, Karl et al. 1988, Jumars et al. 1989, Alldredge et al. 1990, Banse 1990, Lampitt et al. 1990). Several processes are involved in the degradation of particles. One of these, leaching (i.e. loss of soluble material) of organic compounds and elements from biogenic particles (Gardner et al. 1983, Collier \& Edmond 1984, Knauer et al. 1984), is potentially very important but remains poorly understood.

While the release of some elements from biogenic particles may be influenced by degradation processes, no attempt has been made to combine the elemental release rates with particle degradation rates, with the exception of phytoplankton (Lee \& Fisher 1992, Fisher \& 
Wente 1993). Such information is essential for quantifying and modeling the impact of sinking biogenic particles on elemental transport and cycling in the ocean.

To address this deficiency, we have conducted laboratory radiotracer experiments to provide a quantitative assessment of the degradation and elemental release rates from zooplankton carcasses and fecal pellets. We have assessed the fate of $C$ in this debris and also compared 3 elements - Zn, an essential transition metal, Se, an essential metalloid, and Am, a nonessential actinide. All of these elements are concentrated out of seawater by phytoplankton and can be transferred to herbivorous zooplankton (Fisher et al. 1991a, Reinfelder \& Fisher 1991). Their retention in zooplankton debris was compared with that of C. Further, the influence of poisons on elemental release rates was determined to distinguish between biologically mediated and physical/chemical processes.

\section{MATERIALS AND METHODS}

The calanoid copepods Acartia tonsa and Temora longicornis were collected from coastal waters off Long Island, New York, USA, using a $63 \mu \mathrm{m}$ mesh. Adults were separated and maintained in the laboratory in $35 \%$ glass-fiber filtered (GF/C) seawater at $18^{\circ} \mathrm{C}$ and fed the diatom Thalassiosira pseudonana (clone $3 \mathrm{H}$ ) and the haptophyte Isochrysis galbana (clone Iso) prior to experiments.

Radiolabeled copepod fecal pellets and carcasses were collected after feeding on radiolabeled phytoplankton which had been prepared as follows. The 2 algal species were maintained in unialgal, clonal culture in sterile-filtered ( $0.2 \mu \mathrm{m}$ Nuclepore filter), $35 \%$ surface seawater (collected $8 \mathrm{~km}$ off Southampton, New York) enriched with f/2 nutrients (Guillard \& Ryther 1962). Experimental inocula, taken from each algal stock culture in late log phase, were resuspended off of $1 \mu \mathrm{m}$ Nuclepore filters (Thalassiosira pseudonana) and centrifuged out of their media (Isochrysis galbana) and added to three $1 \mathrm{l}$ Erlenmeyer flasks. Each flask contained $400 \mathrm{ml}$ sterile-filtered seawater, enriched with $\mathrm{f} / 2$ nutrients minus $\mathrm{Cu}, \mathrm{Zn}$ and EDTA. Two of the flasks were inoculated with $T$. pseudonana, and a third with $I$. galbana to give an initial cell density of $5.0 \times 10^{4} \mathrm{ml}^{-1}$. One flask of $T$. pseudonana received $37 \mathrm{kBq}{ }^{241} \mathrm{Am}\left(t_{1 / 2}=433 \mathrm{yr}\right.$, from Amersham; $37 \mathrm{kBq}=1 \mu \mathrm{Ci}$ ) in $251 \mu \mathrm{l}$ of $3 \mathrm{~N} \mathrm{HNO}_{3}$, $37 \mathrm{kBq}{ }^{75} \mathrm{Se}\left(t_{1 / 2}=120 \mathrm{~d}\right.$, from Amersham $)$ in $39 \mu \mathrm{lof}$ $0.5 \mathrm{~N} \mathrm{HCl}$, and $148 \mathrm{kBq}{ }^{65} \mathrm{Zn}\left(t_{1 / 2}=244 \mathrm{~d}\right.$, from Amersham) in $127 \mu \mathrm{l}$ of $0.1 \mathrm{~N} \mathrm{HCl}$. Since the isotopes were in dilute acids (Ultrex), immediately prior to addition of the isotopes, the flask received appropriate amounts ( $\mu$ l quantities) of dilute Suprapur $\mathrm{NaOH}$ to ensure that the $\mathrm{pH}$ of the water was 8.0 after the isotope additions. The remaining flasks of $T$. pseudonana and $I$. galbana each received $370 \mathrm{kBq}{ }^{14} \mathrm{C}$ (as $\mathrm{NaH}^{14} \mathrm{CO}_{3}$ in distilled water, $\mathrm{pH}$ 8.4). The isotope additions resulted in total metal additions of $290 \mathrm{ng} \mathrm{Am} \mathrm{(1.20} \mathrm{nM),} 29 \mathrm{ng}$ Se (0.38 nM) and $4.0 \mathrm{ng} \mathrm{Zn}$ ( $64 \mathrm{pM}$ ).

The cultures were incubated on a $14 \mathrm{~h}$ light: $10 \mathrm{~h}$ dark cycle at $18 \pm 1{ }^{\circ} \mathrm{C}$ for $4 \mathrm{~d}$. Periodically, the quantity of each isotope associated with cells was determined by filtering a $10 \mathrm{ml}$ aliquot from each culture through a $0.2 \mu \mathrm{m}$ Nuclepore filter, following established procedures (Fisher et al. 1983a), and a $1 \mathrm{ml}$ aliquot was taken for cell counting by hemacytometer. The cells underwent 5 to 6 divisions, yielding final cell densities of 1.7 to $2.0 \times 10^{6}$ cells $\mathrm{ml}^{-1}$. After the $4 \mathrm{~d}$ incubation period, each culture was resuspended via Nuclepore filtration (Thalassiosira pseudonana) or centrifugation (Isochrysis galbana) into 3 different feeding vessels containing $2 \mathrm{l}$ of $0.2 \mu \mathrm{m}$-filtered seawater to give cell densities of $1 \times 10^{5} \mathrm{mi}$. This corresponds to $6.1 \times 10^{9} \mu^{3} \mathrm{l}^{-1}$ or $0.8 \mathrm{mg} \mathrm{Cl^{-1 }}$ of $T$. pseudonana, and

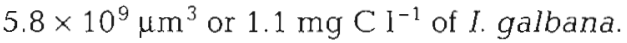

About 200 copepods (Acartia tonsa) were transferred to each feeding vessel containing either Thalassiosira pseudonana labeled with ${ }^{14} \mathrm{C}, T$. pseudonana with ${ }^{241} \mathrm{Am}-{ }^{75} \mathrm{Se}-{ }^{65} \mathrm{Zn}$, or Isochrysis galbana with ${ }^{14} \mathrm{C}$. Copepods were separated by a $210 \mu \mathrm{m}$ Nitex mesh above the bottom of the vessel so that any fecal pellets produced were separated from the copepods above. The fecal pellets produced in the first $2 \mathrm{~h}$ of feeding on radiolabeled food were discarded to eliminate fecal pellets composed of unlabeled food. During the feeding, fecal pellets were collected from the feeding container within $2 \mathrm{~h}$ of production and rinsed several times with $0.2 \mu \mathrm{m}$ filtered seawater. One hundred fecal pellets were transferred via wide-bore pipet into $50 \mathrm{ml}$ snap-top plastic vials. After allowing the copepods to empty undigested radioactive food by feeding on unlabeled food (same species and cell density) for $12 \mathrm{~h}$, copepods fed radiolabeled food for $5 \mathrm{~d}$ were killed by drying in air on a Nitex mesh for about 5 min. Twenty dead copepods from each food source were transferred to each of 3 other vials. The vials, containing fecal pellets or carcasses, were measured for initial total radioactivity (see below) and were then filled with GF/C filtered seawater. Similarly, radiolabeled fecal pellets and carcasses were collected by feeding the copepod Temora longicornis with ${ }^{241} \mathrm{Am}-{ }^{75} \mathrm{Se}-{ }^{65} \mathrm{Zn}$ labeled $T$ pseudonana cells; $T$ longicornis were not fed ${ }^{14} \mathrm{C}$-labeled food.

The fecal pellets and carcasses were incubated in the dark for up to $1 \mathrm{mo}$ in GF/C-filtered seawater, or $\mathrm{GF} / \mathrm{C}$-filtered seawater poisoned with $0.9 \mathrm{mM} \mathrm{HgCl}_{2}$, at either $18 \pm 1^{\circ} \mathrm{C}$ or $2 \pm 1^{\circ} \mathrm{C}$. During the incubation, samples were shaken gently daily to minimize potential concentration gradients. Periodically, the radio- 
activity of gamma-emitting radioisotopes $\left({ }^{241} \mathrm{Am}{ }^{75} \mathrm{Se}\right.$, ${ }^{65} \mathrm{Zn}$ ) retained by the particles was measured by counting each vial (typically a 5 min count was made) after the upper $45 \mathrm{ml}$ of seawater was gently removed by pipetting. Appropriate corrections were made for the radioactivity associated with the $5 \mathrm{ml}$ of water remaining in the vial. Immediately after the radioactivity was determined, a fresh batch of $45 \mathrm{ml} \mathrm{GF/C-filtered}$ seawater for each temperature (pre-equilibrated at the incubation temperatures and containing the appropriate amount of $\mathrm{HgCl}_{2}$, if necessary) was added to each vial and the vials were returned to their incubators.

${ }^{14} \mathrm{C}$ activity was partitioned into 3 fractions as in Lee \& Fisher (1992): particulate $(>0.2 \mu \mathrm{m})$, dissolved organic ${ }^{14} \mathrm{C}(<0.2 \mu \mathrm{m})$, and remineralized ${ }^{14} \mathrm{C}\left({ }^{14} \mathrm{CO}_{2}\right)$. Briefly, at each sample time, 1 vial from each treatment was removed, gently shaken, and filtered through a $0.2 \mu \mathrm{m}$ Nuclepore filter. The particles retained on the filter were transferred to a scintillation vial containing $10 \mathrm{ml}$ of Aquasol scintillation cocktail. ${ }^{14} \mathrm{C}$ activity associated with the filtered particles was considered particulate. To separate $\mathrm{DO}^{14} \mathrm{C}$ from ${ }^{14} \mathrm{CO}_{2}$, the filtrate was transferred into a $125 \mathrm{ml}$ flask and bubbled vigorously with $\mathrm{N}_{2}$ gas for $15 \mathrm{~min}$ after acidification with concentrated $\mathrm{HCl}(\mathrm{pH}<2)$. Liberated ${ }^{14} \mathrm{CO}_{2}$ was collected in series in 2 scintillation vials each containing $10 \mathrm{ml}$ of $\mathrm{CO}_{2}$ absorber (Carbamate 1). ${ }^{14} \mathrm{C}$ activity in the second vial was not significantly different from background, indicating that almost all of the liberated ${ }^{14} \mathrm{CO}_{2}$ was trapped in the first vial. The radioactivity remaining in the solution after acidification and purging of ${ }^{14} \mathrm{CO}_{2}$ was assumed to be activity associated with $\mathrm{DO}^{14} \mathrm{C}(<0.2 \mu \mathrm{m})$. The $\mathrm{DO}^{14} \mathrm{C}$ was measured in $10 \mathrm{ml}$ of filtrate transferred into a scintillation vial containing $10 \mathrm{ml}$ of Aquasol.

$\mathrm{HgCl}_{2}$ was used to suppress microbial activity in these experiments. However, some poisons can accelerate elemental release from diatom cells (Lee \& Fisher 1992), possibly as a result of displacement or complexation of metals bound to debris. To further examine this question, the effects of 2 poisons, $\mathrm{NaN}_{3}$ and $\mathrm{HgCl}_{2}$, on the release of ${ }^{241} \mathrm{Am},{ }^{75} \mathrm{Se}$ and ${ }^{65} \mathrm{Zn}$ from glass beads and egg albumin particles were tested; glass beads served as representative of end member mineral surfaces, while chicken egg albumin particles served as a model for protein (Fisher \& Teyssié 1986). A boiled egg white was dried for $48 \mathrm{~h}$ at $65^{\circ} \mathrm{C}$, ground with a mortar and pestle, and sieved to produce particles of about 5 to $10 \mu \mathrm{m}$ diameter. Acid-washed glass beads (5 to $10 \mu \mathrm{m}$ diameter) and egg albumin particles were labeled with ${ }^{241} \mathrm{Am},{ }^{75} \mathrm{Se}$ and ${ }^{65} \mathrm{Zn}$ by exposing particles to radioisotopes for $2 \mathrm{~d}$; the suspended particle load was $300 \mathrm{mg} \mathrm{l}^{-1}$ for both particle types. The experimental vessels, water, and radioisotope handling and concentrations were identical to those used for labeling the diatoms. The radiolabeled particles were resuspended into $1.0 \mu \mathrm{m}$ filtered seawater to give the following treatments: sterilized (by autoclaving) seawater incubated at 18 and at $2{ }^{\circ} \mathrm{C} ; \mathrm{HgCl}_{2}(0.9 \mathrm{mM})$ treated seawater at 18 and at $2{ }^{\circ} \mathrm{C} ; \mathrm{NaN}_{3}(154 \mathrm{mM})$ treated seawater at $18^{\circ} \mathrm{C}$; and unsterilized seawater without poisons (microbial treatment) at $18^{\circ} \mathrm{C}$. Retention of radioactivity by the particles was monitored for $4 \mathrm{~h}$ for the glass beads and for $10 \mathrm{~d}$ for the albumin particles.

The radioactivity of ${ }^{241} \mathrm{Am},{ }^{75} \mathrm{Se}$ and ${ }^{65} \mathrm{Zn}$ was determined in a Pharmacia-Wallac LKB CompuGamma with a well-type $\mathrm{NaI}(\mathrm{Tl})$ detector and spectra software to correct for spillover of each isotope into another's counting 'window.' The gamma emissions of ${ }^{241} \mathrm{Am}$ were determined at $60 \mathrm{keV},{ }^{75} \mathrm{Se}$ at $264 \mathrm{keV}$ and ${ }^{65} \mathrm{Zn}$ at $1115 \mathrm{keV}$. A calibration of the detector was made for its energy and counting efficiency with appropriate standards for each of the geometries used. The beta emissions of ${ }^{14} \mathrm{C}$-containing samples were measured with an LKB Rack Beta liquid scintillation counter, using an external standards ratio to correct for quenching. Counting times for all samples were 5 to $10 \mathrm{~min}$ and propagated counting errors were generally $<5 \%$.

\section{RESULTS}

Partitioning of ${ }^{14} \mathrm{C}$ activity from decomposing copepod carcasses and fecal pellets over the $30 \mathrm{~d}$ incubation period is shown in Figs. $1 \& 2$. Retention of ${ }^{14} \mathrm{C}$, ${ }^{241} \mathrm{Am},{ }^{75} \mathrm{Se}$ and ${ }^{55} \mathrm{Zn}$ by zooplankton debris over the incubation period is shown in Figs. 3 to 5 .

Retention of ${ }^{14} \mathrm{C},{ }^{241} \mathrm{Am},{ }^{75} \mathrm{Se}$ and ${ }^{65} \mathrm{Zn}$ by the unpoisoned samples generally decreased according to the equation:

$$
y=100(t+1)^{-b}
$$

where $y=$ percent element remaining in the particles $i$ $=$ time (d); and $b=$ release rate coefficient. Values for $b$, specific for each element and treatment, were estimated from a linear regression analysis of log-transformed data (log percent element retained by particles vs log time); all regressions were significant $(p<0.001)$. Consequently, the instantaneous release rate of each element $(R)$ decreased exponentially over time:

$$
\mathrm{d} y / \mathrm{d} t\left(\% \mathrm{~d}^{-1}\right)=-100 b(t+1)^{(b+1)}
$$

where negative values represent decrease in percent element retained by particles. Values and $95 \%$ confidence intervals for $b, r^{2}$ values for the regression lines, and retention half-times $\left(t_{\mathrm{r} 1 / 2} \mathrm{~s}\right)$ of each element estimated from Eq. 1 are given in Table 1. Table 2 shows rate constants $(R)$ estimated from Eq. 2 for release of ${ }^{14} \mathrm{C},{ }^{241} \mathrm{Am},{ }^{75} \mathrm{Se}$ and ${ }^{65} \mathrm{Zn}$ from copepod fecal pellets and carcasses. 


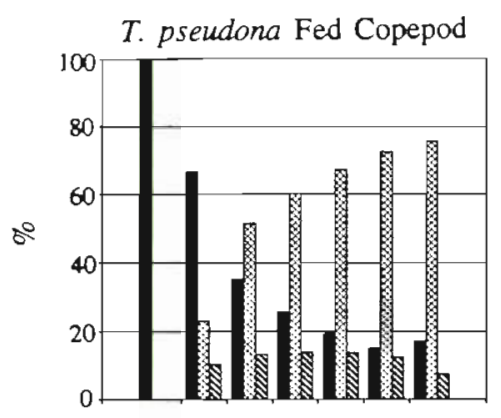

\section{I. galbana Fed Copepod}
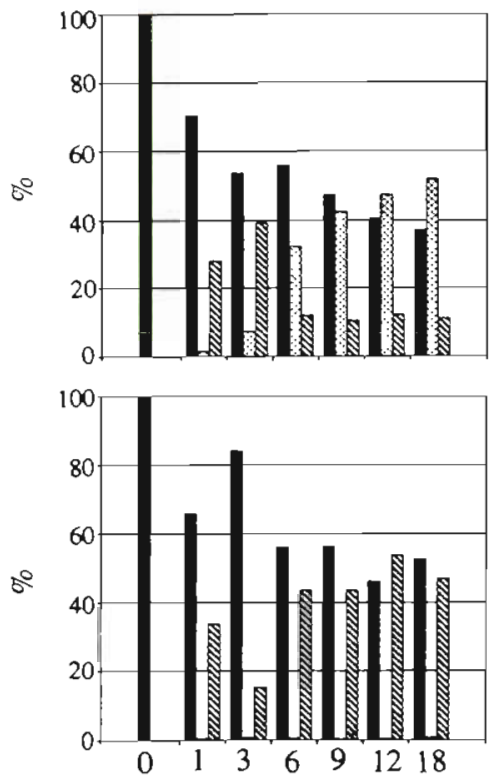

Days (a)

$18^{\circ} \mathrm{C}$

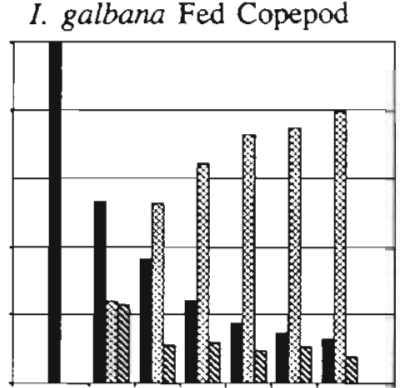

(b)

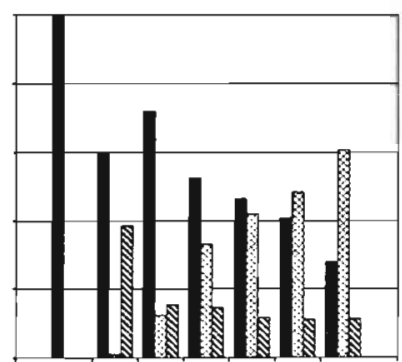

(c) $\mathrm{Hg}^{2+}$

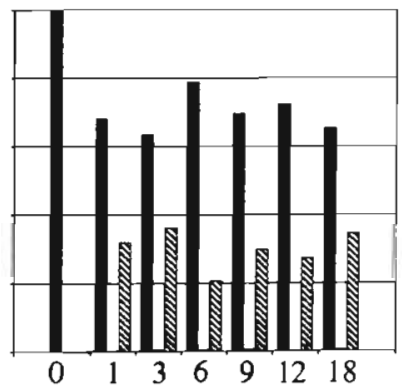

Days
Fig, 1. Acartia tonsa fed Isochrysis galbana and Thalassiosira pseudonana. Partitioning of total ${ }^{14} \mathrm{C}$ activity among (1) particulate, ( ${ }^{14} \mathrm{CO}_{2}$ and $(\mathbb{N}) \mathrm{DO}^{14} \mathrm{C}$ fractions during $18 \mathrm{~d}$ incubations of copepod carcasses at (a) $18^{\circ} \mathrm{C}$, (b) $2{ }^{\circ} \mathrm{C}$, and (c) $18^{\circ} \mathrm{C}$ with $\mathrm{HgCl}_{2}$

Fecal Pellets
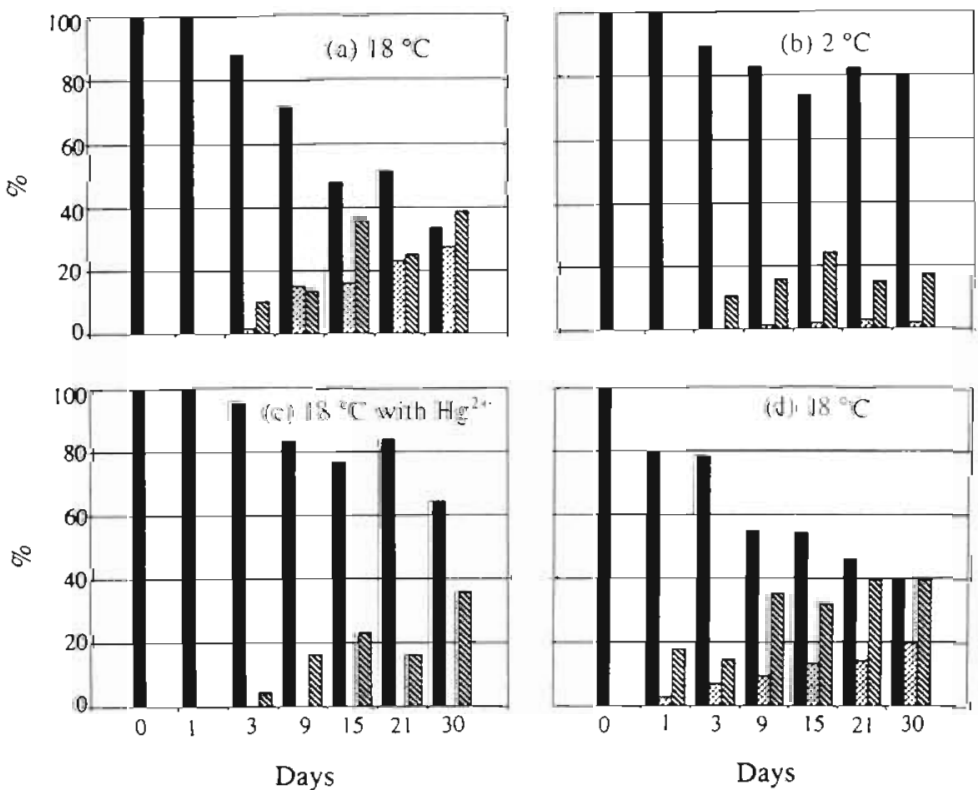

Fig. 2. Acartia tonsa. Partitioning of total ${ }^{14} \mathrm{C}$

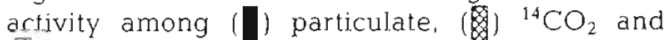
(N) DO ${ }^{14} \mathrm{C}$ fractions during $30 \mathrm{~d}$ incubations of $T$ pseudonana-fed copepod fecal pellets at (a) $18^{\circ} \mathrm{C}$ (b) $2{ }^{\circ} \mathrm{C}$, and (c) $18^{\circ} \mathrm{C}$ with $\mathrm{HgCl}_{2}$; and (d) Isochrysis galbana-fed copepod fecal pellets at $18^{\circ} \mathrm{C}$ 

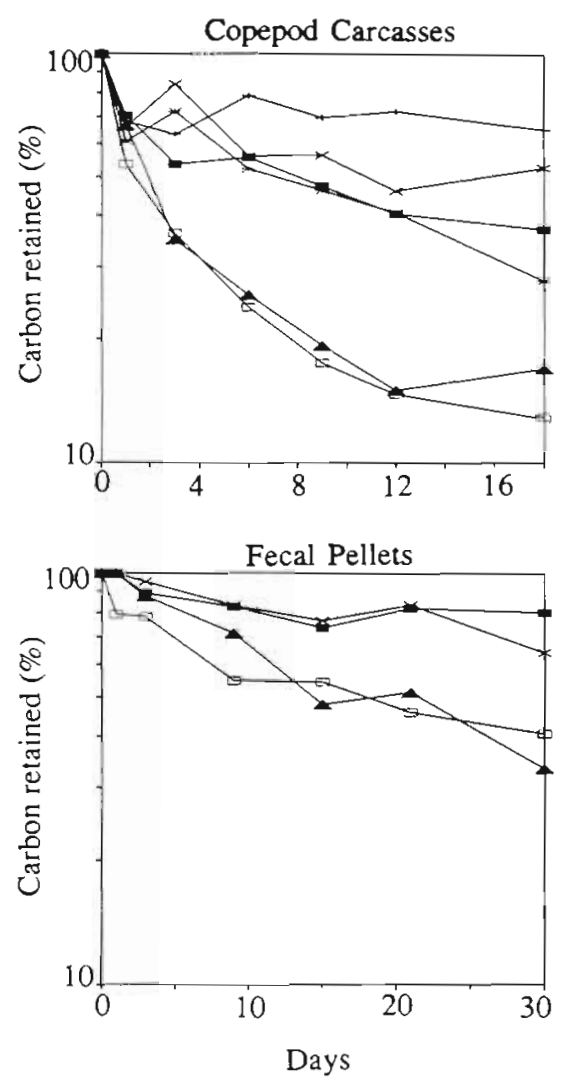

Fig. 3. Acartia tonsa. ${ }^{14} \mathrm{C}$ retained (\%) by Thalassiosira pseudonana-fed copepod debris during $18 \mathrm{~d}$ incubations with $\mathrm{GF} / \mathrm{C}$ filtered seawater at $(-) 18^{\circ} \mathrm{C},(-) 2{ }^{\circ} \mathrm{C}$, and $(\times) 18^{\circ} \mathrm{C}$ with $\mathrm{HgCl}_{2}$ and by Isochrysis galbana-fed copepod debris during $30 \mathrm{~d}$ incubations with $\mathrm{GF} / \mathrm{C}$ filtered seawater at (口) $18^{\circ} \mathrm{C}$, (
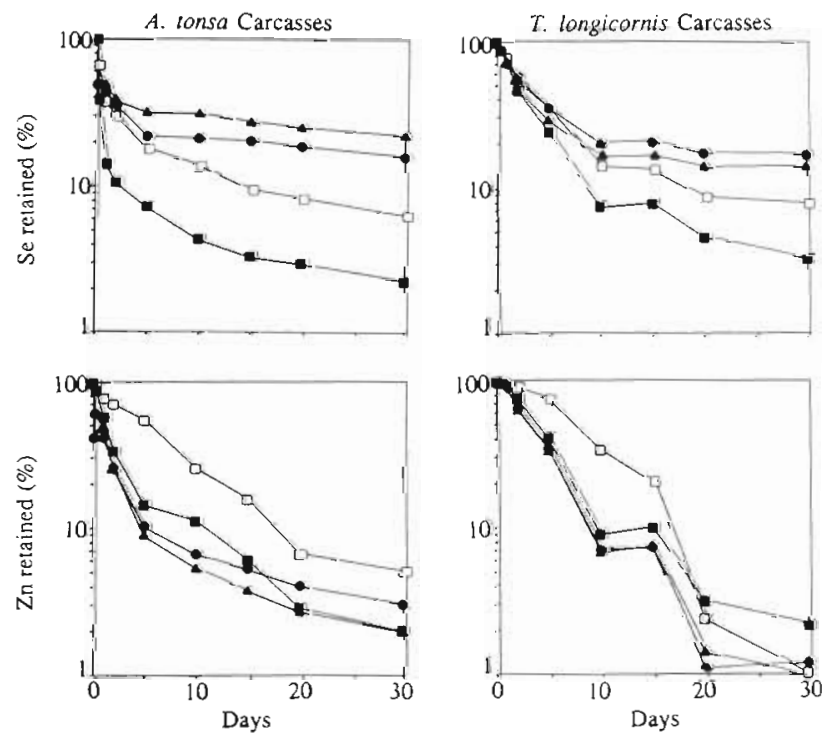

Fig. 4. Acartia tonsa, Temora longicornis. Retention of ${ }^{75} \mathrm{Se}$ and ${ }^{65} \mathrm{Zn}$ in copepod carcasses incubated at $18^{\circ} \mathrm{C}$ : (4) with

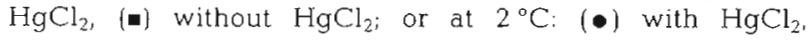
(ㅁ) without $\mathrm{HgCl}_{2}$
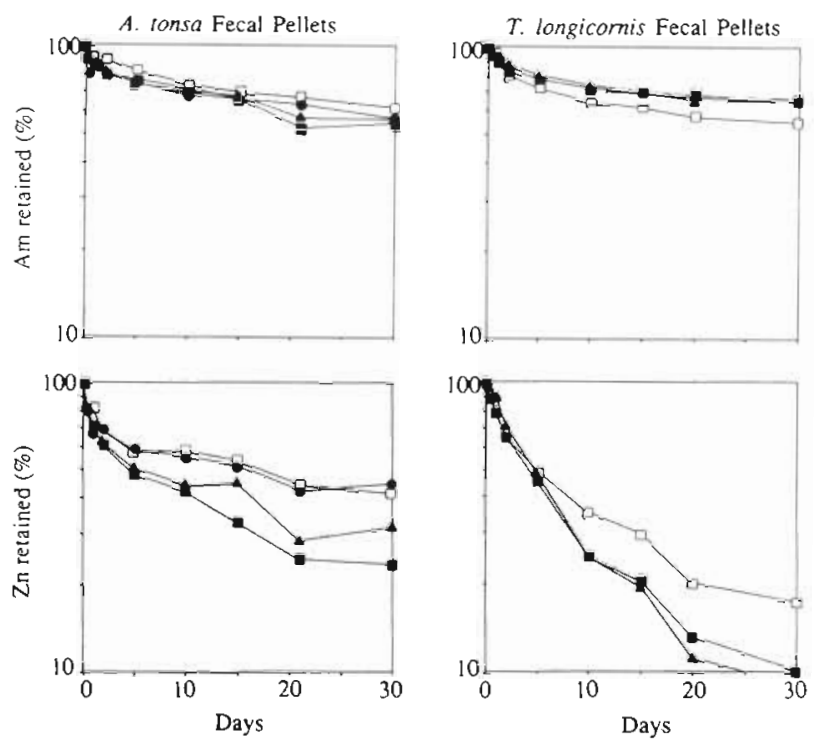

Fig. 5. Acartia tonsa, Temora longicornis. Retention of ${ }^{241} \mathrm{Am}$ and ${ }^{65} \mathrm{Zn}$ in copepod fecal pellets incubated at $18^{\circ} \mathrm{C}:(\mathbf{\Delta})$ with $\mathrm{HgCl}_{2}$, (-) without $\mathrm{HgCl}_{2}$ or at $2^{\circ} \mathrm{C}:(\bullet)$ with $\mathrm{HgCl}_{2}$, (ㅁ) without $\mathrm{HgCl}_{2}$

Results show that degradation of copepod fecal pellets and carcasses was faster at 18 than at $2{ }^{\circ} \mathrm{C}$ and that the release of fecal pellet ${ }^{14} \mathrm{C}$ was slower than that of carcasses (Fig. 3, Table 1). Altering the diet of the copepods (Thalassiosira pseudonana vs Isochrysis galbana) had a negligible effect on the degradation rates of fecal pellets and carcasses. After $30 \mathrm{~d}$ of incubation with microorganisms, about 59 to $65 \%$ of the total fecal pellet ${ }^{14} \mathrm{C}$ was lost (as $\mathrm{DO}^{14} \mathrm{C}$ and ${ }^{14} \mathrm{CO}_{2}$ ) at $18{ }^{\circ} \mathrm{C}$ $\left(20 \%\right.$ at $\left.2{ }^{\circ} \mathrm{C}\right)$; about 82 to $87 \%$ of total copepod carcass ${ }^{14} \mathrm{C}$ was lost after $18 \mathrm{~d}$ at $18{ }^{\circ} \mathrm{C}\left(62\right.$ to $72 \%$ at $\left.2{ }^{\circ} \mathrm{C}\right)$ (Figs. $1 \& 2$ ). The greater microbial remineralization to ${ }^{14} \mathrm{CO}_{2}$ at $18^{\circ} \mathrm{C}$ largely accounted for the higher degradation rates at $18^{\circ} \mathrm{C}$. No attempts were made, however, to enumerate bacteria in these samples.

The greatest changes in the ${ }^{14} \mathrm{C}$ release rates $(R)$, both over time and among treatments, occurred during the first $6 \mathrm{~d}$ of incubation. The instantaneous ${ }^{14} \mathrm{C}$ loss rate for Days 1 to 4 for carcasses and fecal pellets at $18{ }^{\circ} \mathrm{C}$ decreased from 22.1 to $4.5 \% \mathrm{~d}^{-1}(14.3$ to $4.0 \% \mathrm{~d}^{-1}$ at $2{ }^{\circ} \mathrm{C}$ ) and from 10.4 to $3.3 \% \mathrm{~d}^{-1}$ (3.6 to $1.3 \% \mathrm{~d}^{-1}$ at $2{ }^{\circ} \mathrm{C}$ ), respectively (Table 2 ). ${ }^{14} \mathrm{C}$ loss rates for Days 6 to 30 decreased from ca 2 to ca $0.2 \% \mathrm{~d}^{-1}$, regardless of incubation temperature and particle type.

Microbial activity was effectively suppressed by $0.9 \mathrm{mM} \mathrm{HgCl}_{2}$, as indicated by the lack of released ${ }^{14} \mathrm{CO}_{2}$ (Figs. 1c \& 2c). Even without microbial activity, however, the carcasses and fecal pellets incubated with $0.9 \mathrm{mM} \mathrm{HgCl}_{2}$ released up to half the ${ }^{14} \mathrm{C}$ lost by particles incubated with microorganisms. This leach- 
Table 1 . Calculated retention half-times $\left(t_{+1 / 2}\right)$, release rate coefficients $(b), 95 \%$ confidence limits of $b$, and $r^{2}$ values of regression lines $\left[y=100(t+1)^{-b}\right]$ describing elemental release from particles. CC: copepod carcass; FP: fecal pellet; A: Acartia tonsa; T: Temora longicornis; Ig: fed with Isochrysis galbana; Tp: fed with Thalassiosira pseudonana

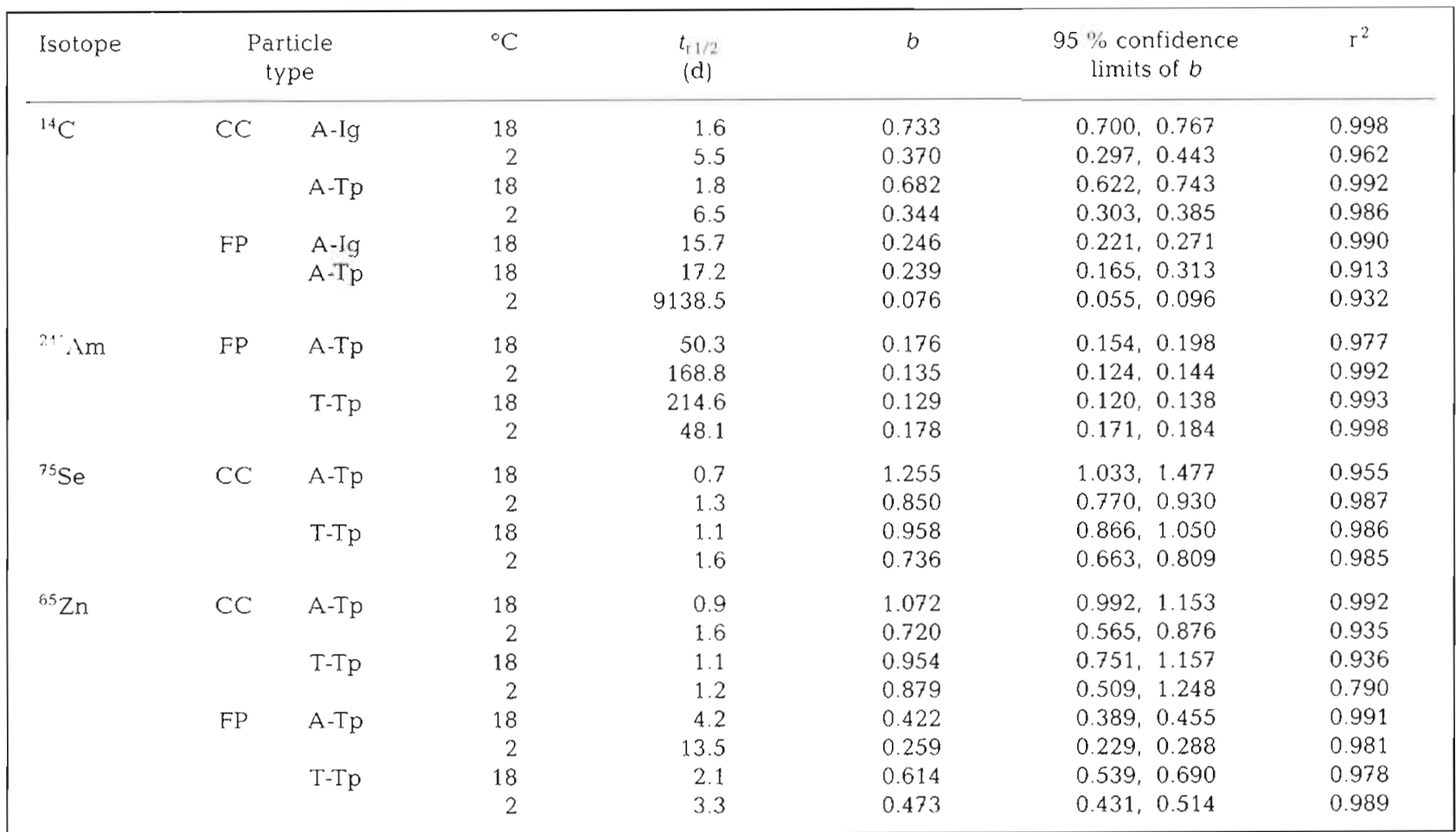

Table 2. Elemental release rates $\left(\% \mathrm{~d}^{-1}\right)$ estimated from the equation: $\mathrm{d} y / \mathrm{d} t(R)=-100 b(t+1)^{-(b+1)}$ for periods up to $30 \mathrm{~d}$. CC: copepod carcass; FP: fecal pellet; A: Acartia tonsi; $T$. Temora longicornis; Ig: fed with Isochrysis galbana; Tp; fed with Thalassiosira pseudonana

\begin{tabular}{|c|c|c|c|c|c|c|c|c|c|c|c|}
\hline \multirow{3}{*}{$\begin{array}{l}\text { Isotope } \\
{ }^{14} \mathrm{C}\end{array}$} & \multirow{2}{*}{\multicolumn{2}{|c|}{$\begin{array}{c}\text { Particle } \\
\text { type }\end{array}$}} & \multirow{3}{*}{$\frac{{ }^{\circ} \mathrm{C}}{18}$} & \multicolumn{8}{|c|}{ Time (d) } \\
\hline & & & & \multirow{2}{*}{$\begin{array}{c}1 \\
22.1\end{array}$} & \multirow{2}{*}{$\begin{array}{c}2 \\
10.9\end{array}$} & \multirow{2}{*}{$\begin{array}{c}3 \\
6.6\end{array}$} & \multirow{2}{*}{$\begin{array}{c}4 \\
4.5\end{array}$} & \multirow{2}{*}{$\begin{array}{c}6 \\
2.0\end{array}$} & \multirow{2}{*}{$\frac{10}{1.1}$} & \multirow{2}{*}{$\begin{array}{l}20 \\
0.4\end{array}$} & \multirow{2}{*}{$\begin{array}{c}30 \\
0.2\end{array}$} \\
\hline & $\mathrm{CC}$ & $A-I g$ & & & & & & & & & \\
\hline & & & 2 & 14.3 & 8.2 & 5.5 & 4.1 & 2.1 & 1.4 & 0.6 & 0.3 \\
\hline & & $A-T p$ & 18 & 21.3 & 10.7 & 6.6 & 4.6 & 2.1 & 1.2 & 0.4 & 0.2 \\
\hline & & & 2 & 13.6 & 7.9 & 5.3 & 4.0 & 2.1 & 1.4 & 0.6 & 0.3 \\
\hline & FP & A-lg & 18 & 10.4 & 6.3 & 4.4 & 3.3 & 1.8 & 1.2 & 0.6 & 0.3 \\
\hline & & A-Tp & 18 & 10.1 & 6.1 & 4.3 & 3.3 & 1.8 & 1. 2 & 0.5 & 0.3 \\
\hline & & & 2 & 3.6 & 2.3 & 1.7 & 1.3 & 0.8 & 0.6 & 0.3 & 0.2 \\
\hline \multirow[t]{4}{*}{${ }^{24 !} \mathrm{Am}$} & FP & $A-T p$ & 18 & 7.8 & 4.8 & 3.4 & 2.7 & 1.5 & 1.0 & 0.5 & 0.3 \\
\hline & & & 2 & 6.1 & 3.9 & 2.8 & 2.2 & 1.3 & 0.9 & 0.4 & 0.3 \\
\hline & & T-Tp & 18 & 5.9 & 3.7 & 2.7 & 2.1 & 1.2 & 0.9 & 0.4 & 0.3 \\
\hline & & & 2 & 7.9 & 4.9 & 3.5 & 2.7 & 1.5 & 1.1 & 0.5 & 0.3 \\
\hline \multirow[t]{4}{*}{${ }^{75} \mathrm{Se}$} & $\mathrm{CC}$ & A-Tp & 18 & 26.3 & 10.5 & 5,5 & 3.3 & 1.2 & 0.6 & 0.1 & 0.1 \\
\hline & & & 2 & 23.6 & 11.1 & 6.5 & 4.3 & 1.8 & 1.0 & 0.3 & 0.1 \\
\hline & & $T-T p$ & 18 & 24.7 & 11.1 & 6.3 & 4.1 & 1.6 & 0.9 & 0.2 & 0.1 \\
\hline & & & 2 & 22.1 & 10.9 & 6.6 & 4.5 & 2.0 & 1.1 & 0.4 & 0.2 \\
\hline \multirow[t]{8}{*}{${ }^{65} \mathrm{Zn}$} & $\mathrm{CC}$ & $\hat{A}-T p$ & 18 & 25.5 & 11.0 & 6.1 & 3.8 & 1.4 & 0.7 & 0.2 & 0.1. \\
\hline & & & 2 & 21.9 & 10.9 & 6.6 & 4.5 & 2.0 & 1.2 & 0.4 & 0.2 \\
\hline & & $T-T p$ & 18 & 24.6 & 11.1 & 6.4 & 41 & 1.6 & 0.9 & 0.2 & 0.1 \\
\hline & & & 2 & 23.9 & 11.2 & 6.5 & 4.3 & 1.8 & 1.0 & 0.3 & 0.1 \\
\hline & $\mathrm{FP}$ & A-Tp & 18 & 15.7 & 8.8 & 5.9 & 4.3 & 2.2 & 1.4 & 0.6 & 0.3 \\
\hline & & & 2 & 10.8 & 6.5 & 4.5 & 3.4 & 1.9 & 1.3 & 0.6 & 0.3 \\
\hline & & $\mathrm{T}-\mathrm{Tp}$ & 18 & 20.1 & 10.4 & 6.6 & 4.6 & 2.1. & 1.3 & 0.5 & 0.2 \\
\hline & & & 2 & 17.0 & 9.4 & 6.1 & 4.4 & 2.2 & 1.4 & 0.5 & 0.3 \\
\hline
\end{tabular}


ing of ${ }^{14} \mathrm{C}$ from $\mathrm{Hg}$-treated fecal pellets as $\mathrm{DO}^{14} \mathrm{C}$ was gradual and proceeded at a rate of $1.25 \% \mathrm{~d}^{-1}$ over the $30 \mathrm{~d}$ incubation period. In contrast, in Hg-treated samples about $35 \%$ of total carcass ${ }^{14} \mathrm{C}$ leached out within the first $24 \mathrm{~h}$, after which there was little change. In unpoisoned samples, most of the $\mathrm{DO}^{14} \mathrm{C}$ released by leaching from carcasses was remineralized to ${ }^{14} \mathrm{CO}_{2}$ (Fig. 1), whereas only a small fraction of the released $\mathrm{DO}^{14} \mathrm{C}$ from fecal pellets was remineralized to ${ }^{14} \mathrm{CO}_{2}$ (Fig. 2b). Thus, by $30 \mathrm{~d}$, the fraction of unutilized $\mathrm{DO}^{14} \mathrm{C}$ increased to about $40 \%$ in the unpoisoned fecal pellet samples.

The C degradation data of Acartia tonsa fecal pellets and carcasses were combined with metal and metalloid data by plotting $C$ vs trace elements retained by particles for each sample throughout the incubation periods (Fig. 6). Least squares fits of the data for metals and $\mathrm{C}$ were calculated from unpoisoned samples and are also presented in Fig. 6. A linear model was applied to the ${ }^{65} \mathrm{Zn}$-carcass data and for all other data a power function was used (Fig. 6). These lines provide comparisons of metal retention normalized to $\mathrm{C}$ in a way that is independent of temperature or microbial activity. Generally, ${ }^{241} \mathrm{Am}$ was retained for longer

\section{Copepod Carcasses}
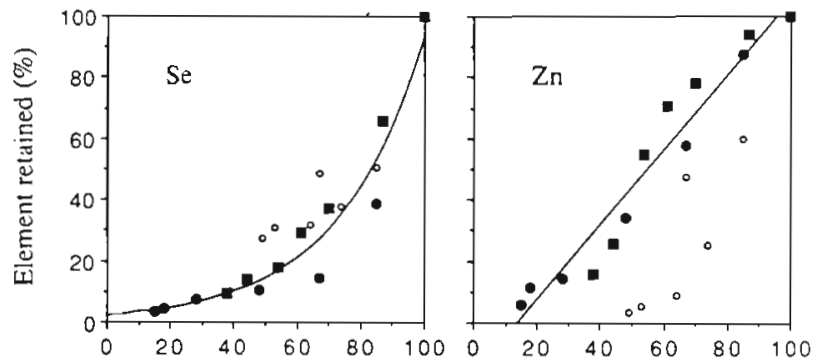

Fecal Pellets
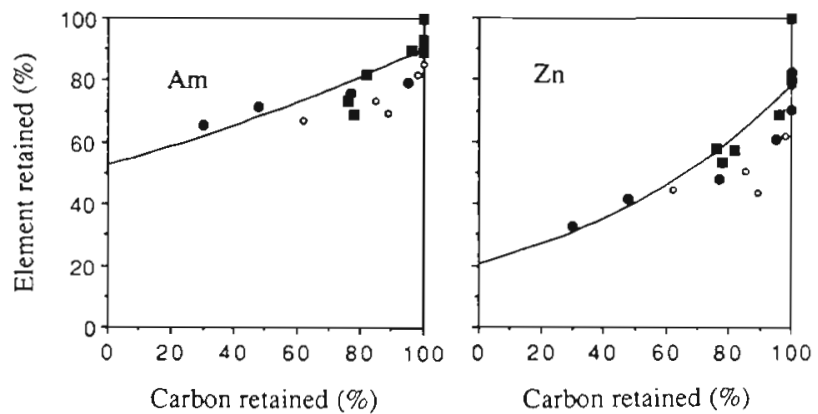

Fig. 6. Acartia tonsa. Retention of ${ }^{75} \mathrm{Se}$ and ${ }^{65} \mathrm{Zn}$ by copepod carcasses and ${ }^{241} \mathrm{Am}$ and ${ }^{65} \mathrm{Zn}$ by copepod fecal pellets incubated at (1) $18^{\circ} \mathrm{C},(-) 2{ }^{\circ} \mathrm{C}$, and (o) $18^{\circ} \mathrm{C}$ with $\mathrm{HgCl}_{2}$ as a function of $\mathrm{C}$ retained. For ${ }^{75} \mathrm{Se}$ in carcasses, $y=2.18 \times 10^{0016 x}$, $\mathrm{r}^{2}=0.947$. For ${ }^{65} \mathrm{Zn}$ in carcasses, $y=-17.04+1.215 x, \mathrm{r}^{2}=$ 0.947 . For ${ }^{65} \mathrm{Zn}$ in fecal pellets, $y=20.36 \times 10^{0.006 x}, \mathrm{r}^{2}=0.830$. For ${ }^{241} \mathrm{Am}$ in fecal pellets, $y=52.37 \times 10^{0.002 x}, \mathrm{r}^{2}=0.720$ periods than $\mathrm{C}$ by fecal pellets, whereas ${ }^{65} \mathrm{Zn}$ was lost at approximately the same rates as $C$, and ${ }^{75}$ Se was lost more rapidly than C (Fig. 6).

Neither temperature nor $\mathrm{HgCl}_{2}$ treatment had a large effect on the ${ }^{241} \mathrm{Am}$ release rate. Because ${ }^{241} \mathrm{Am}$ showed no assimilation in the copepods and ${ }^{75}$ Se was almost completely assimilated by the copepods, the radioactivity of ${ }^{241} \mathrm{Am}$ in the carcasses and of ${ }^{75} \mathrm{Se}$ in the fecal pellets was very low, precluding long-term monitoring

The release rates of both ${ }^{75} \mathrm{Se}$ and ${ }^{65} \mathrm{Zn}$ from copepod carcasses were generally faster at 18 than at $2{ }^{\circ} \mathrm{C}$ (Fig. 4). There was no significant difference between release rate coefficients $(b)$ for ${ }^{75} \mathrm{Se}$ and ${ }^{65} \mathrm{Zn}$ from carcasses of Acartia tonsa and Temora longicornis. Release of ${ }^{75} \mathrm{Se}$ from $A$. tonsa carcasses was initially faster than the release of $C$ but eventually slowed to less than that of $\mathrm{C}$ (Fig. 6). Release of ${ }^{65} \mathrm{Zn}$ from the same carcasses was slightly faster than ${ }^{14} \mathrm{C}$ release, with a slope of 1.2 and a $y$ intercept of $-17 \%$, indicating that all the ${ }^{65} \mathrm{Zn}$ should be lost from the carcasses when some $C$ remains (assuming this relationship can be extrapolated to periods longer than the incubations performed here). Copepod carcasses treated with $\mathrm{HgCl}_{2}$ retained more ${ }^{75} \mathrm{Se}$ but less ${ }^{65} \mathrm{Zn}$ than unpoisoned samples. Carcasses retained ${ }^{65} \mathrm{Zn}$ less effectively than did fecal pellets, where the ${ }^{65} \mathrm{Zn}$ release rate was slower than the ${ }^{14} \mathrm{C}$ loss rate.

The changes in ${ }^{241} \mathrm{Am},{ }^{75} \mathrm{Se}$ and ${ }^{65} \mathrm{Zn}$ release rates from both types of debris were similar to those changes seen with ${ }^{14} \mathrm{C}$ in that the most pronounced changes occurred within the first $6 \mathrm{~d}$ of incubation, with no appreciable differences in rates thereafter (Table 2). Instantaneous loss rates from Days 1 to 4 decreased from 7.9 to $2.1 \% \mathrm{~d}^{-1}$ for ${ }^{241} \mathrm{Am}$ in fecal pellets, from 26.3 to $3.3 \% \mathrm{~d}^{-1}$ for ${ }^{75} \mathrm{Se}$ in carcasses, from 25.5 to $1.4 \% \mathrm{~d}^{-1}$ for ${ }^{65} \mathrm{Zn}$ in carcasses and from 20.1 to $3.4 \% \mathrm{~d}^{-1}$ in fecal pellets (Table 2 ). The calculated $t_{\mathrm{r} 1 / 2}$ 's ranged from 48 to $215 \mathrm{~d}$ for ${ }^{241} \mathrm{Am}$ in fecal pellets (although differences in retention curves for ${ }^{241} \mathrm{Am}$ were relatively small and inconsistent in response to temperature; Fig. 5). These $t_{\mathrm{r} 1 / 2}$ 's were 1 to 2 orders of magnitude greater than for ${ }^{75} \mathrm{Se}$ and ${ }^{65} \mathrm{Zn}$, which ranged from 0.7 to $1.6 \mathrm{~d}$ for ${ }^{75} \mathrm{Se}$ in carcasses, and from 2.1 to $4.2 \mathrm{~d}$ for ${ }^{65} \mathrm{Zn}$ in fecal pellets at $18^{\circ} \mathrm{C}\left(3.3\right.$ to $13.5 \mathrm{~d}$ at $\left.2^{\circ} \mathrm{C}\right)$ and 0.9 to $1.6 \mathrm{~d}$ for ${ }^{65} \mathrm{Zn}$ in carcasses (Table 1).

The retention curves of ${ }^{241} \mathrm{Am},{ }^{75} \mathrm{Se}$ and ${ }^{65} \mathrm{Zn}$ by glass beads and egg albumin particles are shown in Fig. 7. About 20 to $30 \%$ more ${ }^{75} \mathrm{Se}$ and ${ }^{65} \mathrm{Zn}$ were lost from egg albumin particles treated with $\mathrm{HgCl}_{2}$ than with any other treatment, including $\mathrm{NaN}_{3}$. The release rates of ${ }^{241} \mathrm{Am}$ from both particle types and of ${ }^{65} \mathrm{Zn}$ from glass beads showed no appreciable differences among all treatments. Desorption of ${ }^{75} \mathrm{Se}$ from glass beads was not determined since essentially no ${ }^{75} \mathrm{Se}$ sorbed to the glass beads during the $2 \mathrm{~d}$ exposure period. 

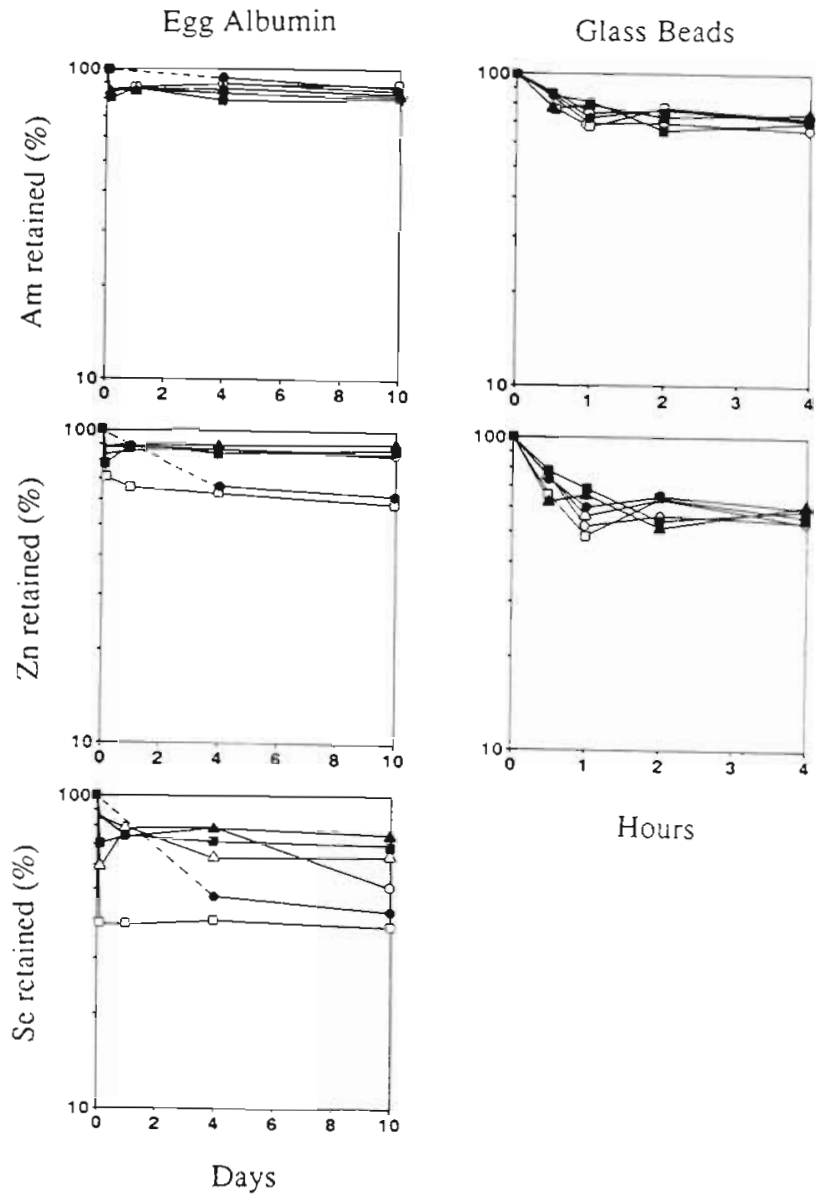

Hours

Fig. 7. Retention of ${ }^{241} \mathrm{Am}$ and ${ }^{65} \mathrm{Zn}$ by glass beads and ${ }^{241} \mathrm{Am}$, ${ }^{75} \mathrm{Se}$ and ${ }^{65} \mathrm{Zn}$ by egg albumin particles incubated in sterile seawater at (1) $18^{\circ} \mathrm{C}$ or (4) $2^{\circ} \mathrm{C}$ and in unsterile seawater $(0)$ at $18^{\circ} \mathrm{C}$ without poisons, $(\Delta)$ at $18^{\circ} \mathrm{C}$ with $\mathrm{NaN}_{3},(\square)$ at $18^{\circ} \mathrm{C}$ with $\mathrm{HgCl}_{2}$ and $(\bullet)$ at $2{ }^{\circ} \mathrm{C}$ with $\mathrm{HgCl}_{2}$. Dashed lines denote no samples taken before $4 \mathrm{~d}$

\section{DISCUSSION}

\section{Carbon release}

The rate of loss of ${ }^{14} \mathrm{C}$ from unpoisoned zooplankton debris was both time and temperature dependent, decreasing over time according to a power function. This inverse relationship of loss rate of organic $\mathrm{C}$ and incubation time is consistent with previous findings for phytoplankton detritus (Otsuki \& Hanya 1972, Cole et al. 1984, Biddanda 1988, Lee \& Fisher 1992\} and fecal pellets (Pomeroy et al. 1984, González \& Biddanda 1990).

Rapid leaching of organic ${ }^{14} \mathrm{C}$ was largely responsible for the initial higher ${ }^{14} \mathrm{C}$ loss rate observed in this study. It can be inferred that microbial activity enhanced this rate, especially at $18^{\circ} \mathrm{C}$, since greater quantities of particulate ${ }^{14} \mathrm{C}$ were lost from unpoisoned particles than from poisoned samples during the first

few days of incubation. Other studies have also shown that microbial biomass and activity on decomposing biogenic debris are greatest at the beginning of particle decomposition and decline over time (Andrews et al. 1984, Pomeroy et al. 1984, Peduzzi \& Herndl 1986 González \& Biddanda 1990). These results indicate that a $C$ loss rate calculated from 2 end point determinations, assuming linear decay rate, is likely to underestimate the rate for initial decomposition periods and to overestimate it for later periods of decomposition. Similarly, $\mathrm{C}$ flux rates assessed with unpoisoned sediment traps, assuming linear decay rate, may be overestimates for long deployments and underestimates for short deployments.

The ${ }^{14} \mathrm{C}$ loss rates from fecal pellets measured here were comparable to those $\left(6 \% \mathrm{~d}^{-1}\right.$ at $18^{\circ} \mathrm{C}, 1.1 \% \mathrm{~d}^{-1}$ at $5^{\circ} \mathrm{C}$ ) reported for fecal pellets collected from natural assemblages (Roy \& Poulet 1990), but higher than those ( 1 to $1.8 \% \mathrm{~d}^{-1}$ ) reported for fecal pellets of the copepod Calanus pacificus (Jacobsen \& Azam 1984). The decay rates in this study also are comparable to the $6 \% \mathrm{~d}^{-1}$ measured in situ for bulk material (mostly herbivore fecal pellets) collected in a sediment trap in the upper $1000 \mathrm{~m}$ (Lorenzen et al. 1983), and the 0.1 to $1 \% \mathrm{~d}^{-1}$ estimated for a variety of biogenic particles in unpoisoned sediment traps deployed at depths $>2700 \mathrm{~m}$ (Gardner et al. 1983). The rates of $\mathrm{C}$ loss observed here suggest that degradation of particles sinking in the water column will decrease substantially from surface to deep waters, partially in response to temperature differences and partially to the increasingly refractory nature of the remaining particulate matter after initial decomposition. Flux measurements determined with sediment traps indicate that particles are, in fact, rapidly regenerated in the upper $1000 \mathrm{~m}$ and that $\mathrm{C}$ flux decreases exponentially with depth (Knauer et al. 1979, Hargrave 1985, Martin et al. 1987).

Other studies have noted the significance of protozoans and metazoans in mediating the decomposition of zooplankton fecal pellets (Jacobsen \& Azam 1984 Pomeroy et al. 1984, González \& Biddanda 1990, Lampitt et al. 1990). Lampitt et al. (1990), for example, demonstrated that copepods can enhance the degradation rates of fecal pellets by breaking up their own pellets, and Jacobsen \& Azam (1984) reported that microzooplankton doubled the rate of decomposition of Calanus pacificus fecal pellets held at $18^{\circ} \mathrm{C}$. Therefore, the estimates of $\mathrm{C}$ loss reported here should be considered conservative, since the effects of animal activities were not determined in our experiments. Moreover, the leaching rates in the experiments reported here may be less than those from sinking particles because boundary layer effects on diffusion would be greater in the laboratory, although the model of Jumars et al. (1989) suggests that these differences would be relatively small. 
The greater $C$ degradation of both types of particles at 18 than at $2{ }^{\circ} \mathrm{C}$ may be attributable to greater microbial activity at $18^{\circ} \mathrm{C}$, since the initial leaching of soluble organic $\mathrm{C}$ is reported to be relatively independent of temperature (Cole et al. 1984). Similarly, other studies focusing on the degradation of zooplankton fecal pellets (Turner 1979, Roy \& Poulet 1990) and phytoplankton debris (Iturriaga 1979, Cole et al. 1984, Lee \& Fisher 1992) reported higher particle degradation rates with increasing temperature. The much greater ${ }^{14} \mathrm{C}$ loss from copepod carcasses than fecal pellets (at both temperatures) was due to greater leaching of $\mathrm{DO}^{14} \mathrm{C}$ from carcasses. This may reflect the fact that fecal pellets are composed of unassimilated, presumably refractory phytoplankton fragments, the labile fraction of phytoplankton having been absorbed by animals. Thus, in seawater those zooplankton carcasses not eaten should rapidly decompose. Harding (1973) reported that carcasses of Calanus finmarchicus at $22{ }^{\circ} \mathrm{C}$ were almost completely disintegrated within $3 \mathrm{~d}$, a rate 4 times as rapid as at $4{ }^{\circ} \mathrm{C}$.

Cho \& Azam (1988) and Karl et al. (1988) concluded from studies in the Pacific that large sinking particles are poor substrates for bacterial growth; rather, particles appear to degrade indirectly by free-living bacteria utilizing DOC released from large particles. Cho \& Azam suggested that bacteria attached to particles could solubilize particles via enzymatic hydrolysis. The greater ${ }^{14} \mathrm{C}$ loss rate at 18 than at $2{ }^{\circ} \mathrm{C}$ could be the result of enhanced leaching of $D \mathrm{O}^{14} \mathrm{C}$ caused by microbially mediated solubilization and subsequent utilization by free-living bacteria. Nevertheless, it can be concluded that leaching, even in the absence of microbial activity, could account for a significant amount of the DOC released from biogenic particles.

Lee \& Fisher (1992) reported that phytoplankton cells treated with either $\mathrm{HgCl}_{2}$ or Formalin lost 26 to $29 \%$ of their total cellular C as DOC within $24 \mathrm{~h}$. The observed $\mathrm{DO}^{14} \mathrm{C}$ loss patterns in the poisoned samples could have resulted from differences in leaching mechanisms. Leaching from phytoplankton cells and zooplankton carcasses was presumably due to cellular ${ }^{14} \mathrm{C}$ loss resulting from damages to cell membranes and/or cell lysis. Leaching of $\mathrm{DO}^{14} \mathrm{C}$ from fecal pellets was probably due to the gradual diffusion of solubilized organic material entrapped in fecal pellet matrices.

Jumars et al. (1989) concluded from model calculations that most of the organic solute in fecal pellets would diffuse out of the pellets within minutes of egestion. This was observed with fecal pellets produced by the pontellid copepod Anomalocera patersoni (Fisher et al. 1991a), but not with the fecal pellets in this study. The most likely explanation for the lack of rapid release of DOC from the fecal pellets is that the chitinous peritrophic membrane encapsulating the pellets was relatively impermeable and hindered the diffusion of solute from the particles. We did not examine the degradation of the peritrophic membranes, however several studies have shown that they degrade over periods of several hours to several weeks, depending on temperature (Small \& Fowler 1973, Honjo \& Roman 1977, Turner 1979, Bathelet \& Schelske 1983). It is also possible that diffusion of solute from the fecal pellets occurred before collection or during rinsing, in which case the observed leaching represents solubilization of the remaining material after unassimilated digestive solute was lost. In any case, leaching was a major process responsible for $\mathrm{C}$ loss from the fecal pellets.

There is also an indication that DOC released from carcasses and fecal pellets differ in quality. Most of the DO ${ }^{14} \mathrm{C}$ leached from carcasses at both temperatures was rapidly remineralized to ${ }^{14} \mathrm{CO}_{2}$, and only $10 \%$ of the total ${ }^{14} \mathrm{C}$ released from carcasses persisted as unutilized $\mathrm{DO}^{14} \mathrm{C}$ throughout the incubation. In contrast, only a small fraction of the released $D O^{14} \mathrm{C}$ from fecal pellets at both temperatures was converted to ${ }^{14} \mathrm{CO}_{2}$, and unutilized $\mathrm{DO}^{14} \mathrm{C}$ steadily increased to about $40 \%$ of the total fecal pellet ${ }^{14} \mathrm{C}$ by Day 30 . Thus, up to $40 \%$ of the material excreted by these copepods and ultimately released as DOC from fecal pellets appears to be refractory and a poor food source for microorganisms. This may explain why sinking particles collected from deep waters are sparsely colonized by microorganisms (Ducklow et al. 1985, Wiebe \& Pomeroy 1972).

\section{Metal/metalloid release}

This is the first study to describe the kinetics of metal/metalloid release from zooplankton debris in the context of $C$ release. The results are relevant to understanding processes that affect the remineralization of decomposing planktonic debris during its descent in the water column.

It appears from the data that microbial activity had a negligible effect on the release of ${ }^{241} \mathrm{Am}$ from fecal pellets, since neither temperature nor $\mathrm{HgCl}_{2}$ appreciably affected release rates. Conversely, the release rate of ${ }^{65} \mathrm{Zn}$ from fecal pellets was faster at 18 than at $2{ }^{\circ} \mathrm{C}_{\mathrm{i}} \mathrm{HgCl}_{2}$ treatment had negligible effects on ${ }^{65} \mathrm{Zn}$ retention. The $y$-intercepts of the lines relating retention of ${ }^{241} \mathrm{Am}$ and ${ }^{65} \mathrm{Zn}$ with $\mathrm{C}$ in decomposing fecal pellets were 53 and $20 \%$, respectively (Fig. 6), indicating greater particulate retention of these metals than of $C$.

Differential retention times of these elements were probably due to differences in the compounds to which 
the metals were bound in the fecal pellets and different binding strengths of the elements to individual compounds. Reinfelder \& Fisher (1991) found that $93 \%$ of $\mathrm{Am}, 52$ to $74 \%$ of $\mathrm{Zn}$, and $10 \%$ of Se in Thalassiosira pseudonana were bound to cell surfaces They also showed that copepods assimilate the cytoplasmic fraction of diatoms, including those elements associated with this fraction. The more refractory material in cells, including cell walls, are not assimilated (Reinfelder \& Fisher 1991) and are, in fact, found as major components of zooplankton fecal pellets (Silver \& Bruland 1981, Gowing \& Silver 1983). Thus, the ${ }^{241} \mathrm{Am}$ and ${ }^{65} \mathrm{Zn}$ in the fecal pellets were presumably bound to these refractory materials. ${ }^{241} \mathrm{Am}$ was retained more effectively in the fecal pellets, being largely unaffected by leaching or microbial action, whereas ${ }^{65} \mathrm{Zn}$ retention was clearly influenced by these processes.

The initial rapid loss of ${ }^{241} \mathrm{Am}$ and ${ }^{65} \mathrm{Zn}$ from fecal pellets was primarily attributable to chemical desorption, since about $15 \%$ of the ${ }^{241} \mathrm{Am}$ and $20 \%$ of the ${ }^{65} \mathrm{Zn}$ were lost during the initial period when essentially no ${ }^{14} \mathrm{C}$ was lost from the fecal pellets (Fig. 6). Thus, ${ }^{241} \mathrm{Am}$ bound to cell fragments in the fecal pellets rapidly desorbed to equilibrate with the ${ }^{24 !} \mathrm{Am}$-free ambient seawater, after which any ${ }^{241} \mathrm{Am}$ release was probably due to both desorption and fecal pellet fragmentation leading to decreased particulate surface area. Some of the initial loss of ${ }^{65} \mathrm{Zn}$ may also have resulted from isotope exchange of radioactive ${ }^{65} \mathrm{Zn}$ on the particles with stable $\mathrm{Zn}$ in the seawater (there is no stable Am available for isotope exchange). After the initial ${ }^{65} \mathrm{Zn}$ loss, any subsequent loss probably was due to leaching of dissolved organic compounds to which the ${ }^{65} \mathrm{Zn}$ was bound and to microbial decomposition of cellular $C$.

${ }^{65} \mathrm{Zn}$ was retained more effectively by copepod fecal pellets than by carcasses, as would be expected given the rapid loss of $\mathrm{DO}^{14} \mathrm{C}$ from carcasses and the faster degradation of organic ${ }^{14} \mathrm{C}$ from the carcasses than from the fecal pellets. Analysis of euphausiid fecal pellets together with the animals which produced them and the food that they ate has shown that the fecal pellets were more enriched than the food or the zooplankters in a variety of transition (Fowler 1977) and transuranic (Higgo et al. 1977. Fowler et al. 1983) metals. Greatest differences occurred for those metals (e.g. Am, Pu, Ce, Pb, Eu) which are least assimilated by the zooplankton, and which are most enriched in the fecal pellets (Fowler 1977).

The effects of incubation temperature on ${ }^{75} \mathrm{Se}$ and ${ }^{65} \mathrm{Zn}$ retention in copepod carcasses suggest that microbial activity had a significant effect on their release into the ambient seawater However, ${ }^{75}$ Se was effectively retained in carcasses when treated with
$\mathrm{HgCl}_{2}$, while ${ }^{65} \mathrm{Zn}$ was lost most rapidly from $\mathrm{HgCl}_{2}-$ treated carcasses. The experiment assessing the influence of poisons on elemental release from different particle surfaces showed that elements bound to mineral $\left(\mathrm{SiO}_{2}\right)$ surfaces were not displaced but ${ }^{75} \mathrm{Se}$ and ${ }^{65} \mathrm{Zn}$ bound to protein particles were displaced by $\mathrm{HgCl}_{2}$ but not $\mathrm{NaN}_{3}$. The displacement by $\mathrm{Hg}$ was probably due to the greater affinity of $\mathrm{Hg}$ than of Se or Zn for S ligands in the protein (Sillén \& Martell 1964). The negligible difference observed in ${ }^{65} \mathrm{Zn}$ release rates between samples treated with and without $\mathrm{HgCl}_{2}$ may have been due to 2 opposing processes acting simultaneously. Suppression of microbial activity by $\mathrm{HgCl}_{2}$, which would depress the release rate of ${ }^{65} \mathrm{Zn}$, could have been offset by displacement of the particulate ${ }^{65} \mathrm{Zn}$ by $\mathrm{Hg} .{ }^{75} \mathrm{Se}$ was not displaced from carcasses by $\mathrm{Hg}^{2+}$, suggesting that the ${ }^{75} \mathrm{Se}$ in these particles was covalently bound in protein or selenoamino acids deriving from ingested phytoplankton (Wrench 1978, Fisher \& Reinfelder 1991). The negligible association of ${ }^{75} \mathrm{Se}$ with the glass beads probably reflects the fact that Se can behave analogously to $\mathrm{S}$ and binds to proteins and amino acids.

Loss of ${ }^{75} \mathrm{Se}$ was faster than that of ${ }^{14} \mathrm{C}$ from carcasses in which $>60 \%$ of the initial ${ }^{14} \mathrm{C}$ was still particulate, but slower than ${ }^{14} \mathrm{C}$ after $>40 \%$ of the initial ${ }^{14} \mathrm{C}$ was lost. Similarly, release of ${ }^{65} \mathrm{Zn}$ from carcasses was slightly faster than that of ${ }^{14} \mathrm{C}$. Since $35 \%$ of total carcass ${ }^{14} \mathrm{C}$ leached out within $24 \mathrm{~h}$ and ${ }^{75} \mathrm{Se}$ and ${ }^{65} \mathrm{Zn}$ closely followed ${ }^{14} \mathrm{C}$, it appears that these radioisotopes were associated with soluble organic $\mathrm{C}$. Therefore, leaching of soluble organic material together with microbial activity appear to be the mechanisms most responsible for release of these elements and organic $\mathrm{C}$ from decomposing biogenic particles. Other studies reported rapid release of $\mathrm{Cd}$, Se and $\mathrm{Zn}$ from phytoplankton cells (Fisher \& Wente 1993, Lee \& Fisher 1992) and P, Cd, Ni and Mn from net plankton assemblages (mainly diatoms and copepods) (Collier \& Edmond 1984).

The release rates of ${ }^{241} \mathrm{Am},{ }^{75} \mathrm{Se}$ and ${ }^{65} \mathrm{Zn}$ from zooplankton debris decreased exponentially over time. Comparisons with other studies are difficult because few data exist on metal release from degrading zooplankton debris, and these are generally expressed as linear rates. Combining instantaneous release rates for ${ }^{241} \mathrm{Am},{ }^{75} \mathrm{Se}$ and ${ }^{65} \mathrm{Zn}$ after $1 \mathrm{wk}$ of $<1.4 \% \mathrm{~d}^{-1}$ (Table 2) with sinking rates of zooplankton fecal pellets of $\geq 50 \mathrm{~m} \mathrm{~d}^{-1}$ (Komar et al. 1981) yields estimations that these elements still retained by particles which sank to depths of $300 \mathrm{~m}$ below the euphotic zone are likely to be released very slowly and continue to $\sin \mathrm{k}$ to deep waters. The release rates of these elements, very different in the early stages of loss, eventually converge to similar values. 
The $t_{\mathrm{r} 1 / 2}$ s of ${ }^{241} \mathrm{Am}$ in the copepod fecal pellets were somewhat greater than values for this radioisotope in euphausiid fecal pellets ( 41 and 51 d at 5 and $13^{\circ} \mathrm{C}$. respectively) produced on a diet of radiolabeled Thalassiosira pseudonana cells (Fisher et al. 1983b). The $t_{\mathrm{r} 1 / 2}$ 's for ${ }^{241} \mathrm{Am}$ were 1 to 2 orders of magnitude greater than the $t_{\mathrm{r} 1 / 2} \mathrm{~s}$ of ${ }^{65} \mathrm{Zn}$ and ${ }^{75} \mathrm{Se}$. The $t_{\mathrm{r} 1 / 2} \mathrm{~s}$ of the elements in the debris in this study (labeled via ingestion) are $>t_{\mathrm{r} 1 / 2}$ 's for debris labeled by scavenging. Thus, $t_{\mathrm{r} 1 / 2}$ 's for scavenged ${ }^{241} \mathrm{Am}\left(3.5\right.$ to $32 \mathrm{~d}$ ) and ${ }^{65} \mathrm{Zn}$ ( 0.8 to $4 \mathrm{~d}$ ) in various types of zooplankton fecal pellets and marine snow (at $15^{\circ} \mathrm{C}$ ) (Fisher et al. 1991b) were shorter $\left({ }^{241} \mathrm{Am}\right)$ than or comparable to $\left({ }^{65} \mathrm{Zn}\right)$ values observed here. The $t_{\mathrm{r} 1 / 2}$ 's for ${ }^{75} \mathrm{Se}\left(4.5 \mathrm{~d}\right.$ at $18^{\circ} \mathrm{C}$ and $6 \mathrm{~d}$ at $\left.4{ }^{\circ} \mathrm{C}\right)$ and ${ }^{65} \mathrm{Zn}\left(7.5 \mathrm{~d}\right.$ at $18^{\circ} \mathrm{C}$ and $13 \mathrm{~d}$ at $\left.4{ }^{\circ} \mathrm{C}\right)$ in decomposing diatom cells (Lee \& Fisher 1992) were generally greater than values given here.

Marine phytoplankton can concentrate many metals very appreciably out of seawater, with concentration factors exceeding $10^{5}$ for some metals (IAEA 1985). Zooplankton feeding on this material could influence the cycling of many elements in the ocean (Fisher et al. 1991a, Reinfelder \& Fisher 1991). These studies demonstrated that Se and Zn are efficiently assimilated in zooplankton and should be recycled in surface waters while particle-reactive, unassimilated metals such as Am are largely packaged into fecal pellets. Given the elemental release rates and $t_{\mathrm{r} 1 / 2}$ 's reported here, Se and $\mathrm{Zn}$ associated with copepod carcasses and fecal pellets would be expected to be rapidly released and recycled in surface waters, consistent with oceanographic observations (Whitfield \& Turner 1987). Particle-reactive metals such as Am, which show minimal association with the organic cycle and negligible assimilation in herbivores, are effectively retained in sinking fecal pellets during their descent in the water column, resulting in shorter oceanic residence times (Cherry et al. 1978) and rapid transport to deep water. Scavenging on sinking debris (Fowler et al. 1983, Fisher et al. 1991b) could result in further removal of these metals from the water column.

Acknowledgements. We thank Bruce Brownawell and anonymous reviewers for helpful comments. Contribution No. 853 from the Marine Sciences Research Center. This research was supported by NSF OCE8810657 to N. Fisher.

\section{LITERATURE CITED}

Alldredge, A. L., Granata, T C., Gotschalk, C. C., Dickey, T. D. (1990). The physical strength of marine snow and its implications for particle disaggregation in the ocean. Limnol. Oceanogr. 35: 1415-1428

Andrews, C. C., Karl, D. M., Small, L. F., Fowler, S. W. (1984). Metabolic activity and bioluminescence of oceanic fecal pellets and sediment trap particles. Nature 307: 539-541
Banse, K. (1990). New views on the degradation and disposition of organic particles as collected by sediment traps in the open ocean. Deep Sea Res. 37: 1177-1195

Bathelet, R. W., Schelske, C. L. (1983). Degradation of the peritrophic membrane of fresh-water zooplankton fecal pellets. Trans. Am. Microsc. Soc. 102: 288-299

Biddanda, B. A. (1988). Microbial aggregation and degradation of phytoplankton-derived detritus in seawater. II. Microbial metabolism. Mar. Ecol. Prog. Ser. 42: 89-95

Cherry, R. D., Higgo, J. J. W., Fowler, S. W. (1978). Zooplankton fecal pellets and element residence times in the ocean. Nature 274: 246-248

Cho, B. C., Azam, F. (1988). Major role of bacteria in biogeochemical fluxes in the ocean's interior. Nature 332: $441-443$

Cole, J. J., Likens, G. E., Hobbie, J. E. (1984). Decomposition of planktonic algae in an oligotrophic lake. Oikos 42: $257-266$

Collier, R., Edmond, J. (1984). The trace element geochemistry of marine biogenic particulate matter. Prog. Oceanogr. 13: 113-199

Ducklow, H. W., Hill, S. M., Gardner, W. D. (1985). Bacterial growth and the decomposition of particulate organic carbon collected in sediment traps. Cont. Shelf Res. 4: $445-464$

Fisher, N. S., Bjerregaard, P., Fowler, S. W. (1983a). Interactions of marine plankton with transuranic elements. 1. Biokinetics of neptunium, plutonium, americium, and californium in phytoplankton. Limnol. Oceanogr. 28: $432-447$

Fisher, N. S., Bjerregaard, P., Fowler, S. W. (1983b). Interactions of marine plankton with transuranic elements. 3 Biokinetics of americium in euphausiids. Mar. Biol. 75: $261-268$

Fisher, N. S., Cochran, J. K., Krishnaswami, S., Livingston, H. D. (1988). Predicting oceanic flux of radionuclides on sinking biogenic particles. Nature 335: 622-625

Fisher, N. S., Nolan, C. V., Fowler, S. W. (1991a). Assimilation of metals in marine copepods and its biogeochemical implications. Mar. Ecol. Prog. Ser. 71: 37-43

Fisher, N. S., Nolan, C. V., Fowler, S. W. (1991b). Scavenging and retention of metals by zooplankton fecal pellets and marine snow. Deep Sea Res. 38: 1261-1275

Fisher, N. S., Reinfelder, J. R. (1991). Assimilation of selenium in the marine copepod Acartia tonsa studied with a radiotracer ratio method. Mar. Ecol. Prog. Ser. 70: 157-164

Fisher, N. S., Teyssié, J.-L. (1986). Influence of food composition on the biokinetics and tissue distribution of zinc and americium in mussels. Mar. Ecol. Prog. Ser. 28: 197-207

Fisher, N. S., Wente, M. (1993). Release of trace elements by dying marine phytoplankton. Deep Sea Res. 40: in press

Fowler, S. W. (1977). Trace elements in zooplankton particulate products. Nature 269: 51-53

Fowler, S. W., Knauer, G. A. (1986). Role of large particles in the transport of elements and organic compounds through the oceanic water column. Prog. Oceanogr. 16: 147-194

Fowler, S. W., Ballestra, S., La Rosa, J., Fukai, R. (1983). Vertical transport of particulate-associated plutonium and americium in the upper water column of the Northeast Pacific. Deep Sea Res. 30: 1221-1233

Gardner, W. D., Hinga, K. R., Marra, J. (1983). Observations on the degradation of biogenic material in the deep ocean with implications on accuracy of sediment trap fluxes. J. mar. Res 41: 195-214

González, H., Biddanda, B. (1990). Microbial transformation of metazoan (Idotea granulosa) faeces. Mar. Biol. 106: 285-295 
Gowing, M. M, Silver, M. W. (1983). Origins and microenvironments of bacteria mediating fecal pellet decomposition in the sea. Mar. Biol. 73: 7-16

Guillard, R. R. L., Ryther, J. H. (1.962). Studies of marine planktonic diatoms I. Cyclotella nana Hustedt, and Detonula confervacea (Cleve) Gran. Can. J. Microbiol. 8: 229-239

Harding, G. C. (1973). Decomposition of marine copepods. Limnol. Oceanogr. 18: 670-673

Hargrave, B. T (1985). Particle sedimentation in the ocean. Ecol. Model. 30: 229-246

Higgo, J. J. W., Cherry, R. D., Heyraud, M., Fowler, S. W. (1977). Rapid removal of plutonium from the oceanic surface layer by zooplankton faecal pellets. Nature 266 : $623-624$

Honjo, S., Roman, M. R. (1978). Marine copepod fecal pellets: production, preservation and sedimentation. J. mar. Res. 36: $45-47$

IAEA (1985). Sediment Kds and concentration factors for radionuclides in the marine environments. International Atomic Energy Agency Rep. 247, Vienna

Iturriaga, R. (1979). Bacterial activity related to sedimenting particulate matter. Mar. Biol. 55: 157-169

Jacobsen, T. R., Azam, F. (1984). Role of bacteria in copepod fecal pellet decomposition: colonization, growth rates and mineralization. Bull mar. Sci. 35: 495-502

Jumars, P. A., Penry, D. L., Baross, J. A., Perry, M. J., Frost, B. W. (1989). Closing the microbial loop: dissolved carbon pathway to heterotrophic bacteria from incomplete inges. tion, digestion and absorption in animals. Deep Sea Res. 36: $483-495$

Karl, D. M., Knauer, G. A., Martin, J. H. (1988). Downward flux of particulate organic matter in the ocean: a particle decomposition paradox. Nature 332: 438-441

Knaver, G. A., Karl, D. M., Martin, J. H., Hunter, C. N. (1984). In situ effects of selected preservatives on total carbon, nitrogen and metals collected in sediment traps. J. mar. Res. 42: 445-462

Knauer, G. A., Martin, J. H., Bruland, K. W. (1979). Fluxes of particulate carbon, nitrogen, and phosphorus in the upper water column of the northeast Pacific. Deep Sea Res. 26: $97-108$

Komar, P. D., Morse, A. P., Small, L. F., Fowler, S. W. (1981) An analysis of sinking rates of natural copepod and euphausiid fecal pellets. Limnol. Oceanogr. 26: 172-180

Lampitt, R. S., Noji, T., Bodungen, B. von. (1990). What happens to zooplankton faecal pellets? Implications for material flux. Mar. Biol. 104: 15-23

Lee, B.-G., Fisher, N. S. (1992). Degradation and elemental release rates from phytoplankton debris and their geochemical implications. Limnol. Oceanogr. 37: 1345-1360

This article was submitted to the editor
Lorenzen, C. J., Welschmeyer, Copping, A. E., Vernet, M. (1983). Sinking rates of organic particles. Limnol Oceanogr. 28: 766-769

Martin, J H., Knauer, G. A., Karl, D. M., Broenkow, W. W (1987). VERTEX: carbon cycling in the northeast Pacific Deep Sea Res. 34: 267-285

McCave, I. N. (1975). Vertical flux of particulates in the ocean. Deep Sea Res. 22: 491-502

Otsuki, A., Hanya, T (1972). Production of dissolved organic matter from dead green algal cells. I. Aerobic microbial decomposition. Limnol. Oceanogr. 17: 248-256

Peduzzi, P., Herndl, G. J. (1986). Role of bacteria in decomposition of faecal pellets egested by the epiphyte-grazing gastropod Gibbula umbilicaris. Mar. Biol. 92: 417-424

Pomeroy, L. R., Hanson, R. B., McGillivary, P. A., Sherr, B. F. Kirchman, D., Deibel, D. (1984). Microbiology and chem. istry of fecal products of pelagic tunicates: rates and fates. Bull. mar. Sci. 35: 426-4.39

Reinfelder, J. R., Fisher, N. S. (1991). The assimilation of elements ingested by marine copepods. Science 251: $794-796$

Roy, S., Poulet, S. A. (1990). Laboratory study of the chemical composition of aging copepod fecal material. J. exp. mar. Biol. Ecol. 135: 3-18

Sillén, L. G., Martell, A. E. (1964). Stability constants of metalion complexes. The Chemical Society Spec. Publ. No. 17 London

Silver, M. W., Bruland, K. W. (1981). Differential feeding and fecal pellet composition of salps and pteropods, and the possible origins of the deep-water flora and olive-green 'cells' Mar. Biol. 62: 263-273

Small, L. F., Fowler, S. W. (1973). Turnover and vertical transport of zinc by the euphausiid Meganyctiphanes norvegica in the Ligurian Sea. Mar. Biol, 18: 284-290

Turner, J. T (1979). Microbial attachment to fecal pellets and its possible ecological significance. Trans. Am. Microsc. Soc. 98: 131-135

Wakeham, S. G., Lee, C., Farrington, J. W., Gagosian, R. B. (1984). Biogeochemistry of particulate organic matter in the oceans: results from sediment trap experiments. Deep Sea Res. 31: 509-528

Whitfield, M., Turner, D. (1987). The role of particles in regulating the composition of seawater. In: Stumm, W. (ed.) Aquatic surface chemistry: chemical processes at the particle-water interface. Wiley, New York, p. 457-493

Wiebe, W. J., Pomeroy, L. R. (1972). Microorganisms and their association with aggregates and detritus in sea: a microscopic study. Mem. Ist. Ital. Idrobiol. 29 Suppl: 325-352

Wrench. J. J. (1.978). Selenium metabolism in the marine phytoplankters Tetraselmis tetrathele and Dunaliella minuta. Mar. Biol. 49: 231-236

Manuscript first received: July 2, 1992

Revised version accepted: September 3, 1992 